The University of Southern Mississippi

The Aquila Digital Community

Faculty Publications

$9-1-2009$

\title{
Evaluation of CAY-1, an Experimental, Natural Fungicide, For Control of Strawberry Pathogens
}

\author{
Kenneth J. Curry \\ University of Southern Mississippi, Kenneth.Curry@usm.edu \\ Maritza Abril \\ University of Southern Mississippi, maritza.abrilcastillo@eagles.usm.edu \\ Anthony J. DeLucca \\ USDA-ARS, anthony.delucca@ars.usda.gov \\ Stephen M. Boue \\ United States Department of Agriculture, steven.boue@ars.usda.gov \\ Barbara J. Smith \\ USDA-ARS Southern Horticultural Laboratory, barbara.smith@ars.usda.gov
}

See next page for additional authors

Follow this and additional works at: https://aquila.usm.edu/fac_pubs

Part of the Agricultural Science Commons

\section{Recommended Citation \\ Curry, K. J., Abril, M., DeLucca, A. J., Boue, S. M., Smith, B. J., Wedge, D. E. (2009). Evaluation of CAY-1, an Experimental, Natural Fungicide, For Control of Strawberry Pathogens. Acta Horticulturae, 842, 295-298. Available at: https://aquila.usm.edu/fac_pubs/1}

This Article is brought to you for free and open access by The Aquila Digital Community. It has been accepted for inclusion in Faculty Publications by an authorized administrator of The Aquila Digital Community. For more information, please contact Joshua.Cromwell@usm.edu. 
Authors

Kenneth J. Curry, Maritza Abril, Anthony J. DeLucca, Stephen M. Boue, Barbara J. Smith, and David E. Wedge 


\title{
Evaluation of CAY-1, an Experimental, Natural Fungicide, for Control of Strawberry Pathogens
}

\author{
M. Abril and K.J. Curry \\ Department of Biological Sciences \\ The University of Southern Mississippi \\ Hattiesburg, MS 39406 \\ USA \\ B.J. Smith \\ USDA-Agricultural Research Service \\ Southern Horticultural Laboratory \\ Small Fruit Research Unit \\ Poplarville, MS 39470 \\ USA
}

\author{
A.J. DeLucca and S. Boue \\ United States Department of Agriculture \\ ARS, Southern Regional Research Center \\ New Orleans, LA 70124 \\ USA
D.E. Wedge
USDA-Agricultural Research Service
Thad Cochran National Center
for Natural Products Research
Oxford, MS 38677
USA

Keywords: benomyl, captan, iprodinone, Fragaria $\times$ ananassa, Colletotrichum fragariae, Colletotrichum acutatum, Colletotrichum gloeosporioides

\begin{abstract}
CAY-1 is an experimental, natural product being tested as a potential fungicide. This saponin isolated from Capsicum frutescens interacts with membrane sterols causing leakage of cell components and ultimately cell death in a variety of fungi. CAY-1 and the commercial fungicide captan were tested in an in vitro doseresponse dilution-broth assay. They caused at least $85 \%$ growth inhibition of the fungal pathogens Colletotrichum acutatum, $C$. fragariae and $C$. gloeosporioides when tested at 3.0 $\mu \mathrm{M}$. Even though CAY-1 strongly reduced the growth of these fungal pathogens in laboratory assays and prevented anthracnose development in detached leaf assays, it did not control foliar or fruit rot diseases of strawberry in field trials.
\end{abstract}

\section{INTRODUCTION}

The strawberry industry in the USA accounts for over a quarter of the total world production of strawberries (Fragaria $\times$ ananassa Duch.). Fruit rot diseases cause significant losses to this industry, especially in the southeastern USA where temperature and humidity often favor fungal pathogens. Prevalent diseases in this region include anthracnose fruit rot and crown rot (Colletotrichum spp.) (Smith, 1998), Botrytis gray mold (Botrytis cinerea), leather rot (Phytophthora cactorum), and stem end rot (Gnomonia comari) (Mass, 1998). Controlling these diseases has become challenging as the efficacy of some fungicides has diminished due to development of resistant strains of fungi (Smith and Black, 1993a, b; Peres et al., 2002, 2004), and other fungicides have lost their registration for use on strawberries (Wedge et al., 2007). Natural product-based fungicides are being developed as alternatives to traditional fungicides for use on strawberries. The purpose of this study was to evaluate the efficacy of CAY-1 as a natural product-based fungicide (De Lucca et al., 2002; Renault et al., 2003) in laboratory trials.

\section{MATERIALS AND METHODS}

CAY-1 is a fungicidal steroidal saponin isolated from the ground fruit of cayenne pepper (Capsicum frutescens). The commercial fungicides, benomyl (a methyl benzimidazole carbamate fungicide that is no longer commercially available in the USA), captan (a multisite phthalamide fungicide), and iprodione (a dicarboxymide fungicide) were used as industry standards for efficacy comparison against CAY-1 in laboratory trials. Preparation of pure CAY-1 was performed as previously reported (De Lucca et al., $2002,2006)$. Crude, dry, ground cayenne pepper was aqueously extracted overnight. The slurry was centrifuged, the supernatant filtered, and the pelleted pepper was resuspended in water, allowed to equilibrate for $10 \mathrm{~min}$, and centrifuged as before. The resulting 
supernatant was passed through cheesecloth and the filtered supernatants combined. This extract was then centrifuged at 10,000 RPM for $10 \mathrm{~min}$ at $4^{\circ} \mathrm{C}$, and the supernatant was filtered and freeze-dried. The crude, freeze-dried material was dissolved in water and eluted through a 400 gram $\mathrm{C}_{18}(125 \AA, 55-105 \mu \mathrm{m}$, Waters Corp, Milford, MA, USA) gravity column using a step gradient of methanol: water. The semi-pure CAY-1 eluted in the $75 \% \mathrm{MeOH}$ eluate. The methanol was removed under vacuum and the remaining liquid freeze-dried. Pure CAY-1 was prepared using high pressure liquid chromatography (HPLC) and confirmed by mass spectrometry.

\section{Fungal Isolates and Inoculum Preparation}

Four plant pathogenic fungal species (Colletotrichum acutatum, C. fragariae, $C$. gloeosporioides and Fusarium oxysporum) were grown on potato dextrose agar (PDA) in 9-cm petri dishes and incubated under cool-white fluorescent lights with a $12 \mathrm{~h}$ photoperiod at $\sim 24^{\circ} \mathrm{C}$ as previously described (Abril et al., 2008). Conidia were harvested from 7- to 10-day-old cultures, and the aqueous conidial suspensions were filtered to remove hyphae. The conidial matrix was removed from the conidia by washing each suspension three times as previously described (Abril et al., 2008). The conidia were suspended in mycological liquid medium (Roswell Park Memorial Institute 1640 [RPMI], Life Technologies, Grand Island, NY, USA). Conidial concentrations of the suspensions were determined photometrically (Espinel-Ingrof and Kerkering, 1991; Wedge and Kuhajek, 1998) and adjusted to a final concentration of approximately $10^{6}$ conidia $/ \mathrm{ml}$.

\section{Microtiter Assay}

Differences in mycelial growth in vitro have been used to demonstrate the sensitivity of fungal plant pathogens to natural product-based and commercially available fungicide standards with known modes of action (Wedge et al., 2001). A 96-well culture cluster was prepared for each replicate of each fungal isolate. Two hundred microliters of the buffered fungicide solution containing the conidial suspension were placed in each well of the 96-well culture plates (Corning, Inc., Corning, NY, USA) at fungicide concentrations of $0.3,3.0$, and $30 \mu \mathrm{M}$. Each compound was evaluated in triplicate against a non-inoculated well (negative control) containing the fungicide solution and RPMI at each concentration. The 96-well culture plates were incubated in a growth chamber for $72 \mathrm{~h}$ to allow time for mycelial development past the initial germination times. Growth was evaluated by measuring absorbency of each well at $620 \mathrm{~nm}$ using a microplate photometer (Packard Spectra Count, Packard Instrument Co., Downers Grove, IL, USA).

The 96-well cell culture plates were set up so that eight wells containing the conidial suspension and RPMI served as unamended positive controls and four wells containing RPMI without conidial suspension were used as negative controls. Each test fungicide was run in duplicate at each concentration, and the experiment was repeated three times. Treatments were arranged as a split-plot design where whole plots were the four fungal isolates and sub-plots were the four fungicide solutions at the three doses. Mean absorbency values were used to evaluate fungal growth of three Colletotrichum spp. and $F$. oxysporum at each concentration of the fungicide solution at 48 and $72 \mathrm{~h}$. Mean absorbency values were expressed as percent inhibition/stimulation of fungal growth (\% growth) using the formula:

$\%$ growth $=\underline{[\text { (mean sample absorbency })-(\text { mean unamended control absorbency })]}$ x 100

(mean unamended control absorbency)

Positive numbers indicate stimulation of growth and negative numbers indicate inhibition compared to growth of the fungus on unamended medium.

\section{Data Analysis}

Statistical comparisons were made of fungal growth within each concentration of fungicide for each isolate. Each dose level and response time was analyzed separately. In 
all trials data were evaluated by analysis of variance (ANOVA) using the general linear model procedure (GLM) of Statistical Analysis Systems (SAS) software (Version 9.1). Significant factors were separated and tested using Fisher's protected least significant difference (LSD) tests $(P<0.05)$.

\section{RESULTS AND DISCUSSION}

None of the fungicides in the in vitro dose-response assays greatly inhibited growth of the four fungal species at $0.3 \mu \mathrm{M}$ (Table 1). CAY-1 and captan inhibited the growth of all four species at 3 and $30 \mu \mathrm{M}$ while benomyl inhibited the growth of three of the species, $C$. fragariae, $C$. gloeosporioides and $F$. oxysporum. Benomyl stimulated the growth of $C$. acutatum which supports previous reports that isolates of $C$. acutatum are resistant to benomyl (Smith and Black, $1993 \mathrm{a}, \mathrm{b}$ ). Iprodione was ineffective against all four fungi at the concentrations tested. These initial tests with CAY-1 suggested that it might perform similarly to captan and benomyl against Colletotrichum spp. and $F$. oxysporum.

Results of follow-up field studies (not shown) were disappointing because plants treated with CAY-1 had as much disease as untreated control plants due to injury of fruit and foliage. This damage by CAY-1 (a saponin) could have been due to (1) its detergentlike properties affecting the epidermis of the receptacle of the fruit and the cuticle of the leaves of the strawberry or (2) other compounds present in the semi-purified CAY-1 used in the field trials that were not present in the purified CAY-1 used in the in vitro trials. Improvements in the formulation of CAY-1 might prevent this injury and result in better disease control.

\section{ACKNOWLEDGMENTS}

Mention of a trademark, proprietary product, or vendor does not constitute a guarantee or warranty of the product by the U.S. Dept. of Agriculture and does not imply its approval to the exclusion of other products or vendors that also may be suitable.

\section{Literature Cited}

Abril, M., Curry, K.J., Smith, B.J. and Wedge, D.E. 2008. Improved microassays used to test natural product-based and conventional fungicides on plant pathogenic fungi. Plant Dis. 92:106-112.

De Lucca, A.J., Bland, J.M., Vigo, C.B., Cushion, M., Selitrennikoff, C.P., Peter, J. and Walsh, T.J. 2002. CAY-1, a fungicidal saponin from Capsicum sp. fruit. Med. Mycol. 40:131-137.

De Lucca, A.J., Boue, S., Palmgren, M.S., Maskos, K. and Cleveland, T.E. 2006. Fungicidal properties of two saponins from Capsicum frutescens and the relationship of structure and fungicidal activity. Can. J. Microbiol. 52:336-342.

Espinel-Ingrof, A. and Kerkering, T.M. 1991. Spectrophotometric method of inoculum preparation for the in vitro susceptibility testing of filamentous fungi. J. Clinic Microbiol. 29:393-394.

Maas, J.L. (ed.). 1998. Compendium of Strawberry Diseases, Second Edition. APS Press, St. Paul, MN.

Peres, N.A.R., Souza, N.L., Zitko, S.E. and Timmer, L.W. 2002. Activity of benomyl for control of postbloom fruit drop of citrus caused by Colletotrichum acutatum. Plant Dis. 86:125-130.

Peres, N.A.R., Souza, N.L., Peever, T.L. and Timmer, L.W. 2004. Benomyl sensitivity of isolates of Colletotrichum acutatum and C. gloeosporioides from citrus. Plant Dis. 88:125-130.

Renault, S., De Lucca, A.J., Boue S., Bland, J.M., Vigo, C.P. and Selitrennikoff, C.P. 2003. CAY-1, a novel antifungal compound from cayenne pepper. Med. Mycol. 41:17.

Smith, B.J. 1998. Anthracnose crown rot, p.46-48, Anthracnose fruit rot (black spot), p. 31-33, and Anthracnose leaf spot and irregular leaf spot, p. 24-25 In: J.L. Maas (ed.). 
Compendium of Strawberry Diseases, $2^{\text {nd }}$ edition, APS Press, St. Paul, MN.

Smith, B.J. and Black, L.L. 1993a. In vitro activity of fungicides against Colletotrichum fragariae. Acta Hort. 348:509-512.

Smith, B.J. and Black, L.L. 1993b. In vitro fungicide studies show the occurrence of benomyl-resistant Colletotrichum spp. from strawberry. Adv. Strawberry Res. 12:4248.

Wedge, D.E. and Kuhajek, M.A. 1998. A microbioassay for fungicide discovery. SAAS Bull. Biochem. Biotechnol. 11:1-7.

Wedge, D.E., Curry, K.J., Boudreaux, J., Pace, P. and Smith, B.J. 2001. A microtiter assay demonstrates sensitivity and resistance profiles for Botrytis cinerea isolates from Louisiana strawberry farms. Adv. Strawberry Res. 20:27-33.

Wedge, D.E., Smith, B.J., Quebedeaux, J.P. and Constantin, R.J. 2007. Fungicide management strategies for control of strawberry fruit rot diseases in Louisiana and Mississippi. Crop Prot. 26:1449-1458.

\section{Tables}

Table 1. Efficacy of CAY-1 and three commercial fungicides against four plant pathogenic fungi. Fungal growth is reported as mean percent inhibitions (-) or stimulation $(+)$ for each fungicide at three concentrations after 72 hours growth ${ }^{\mathrm{z}}$.

\begin{tabular}{|c|c|c|c|c|c|c|c|c|c|c|c|c|}
\hline \multirow[b]{3}{*}{ Fungicide } & \multicolumn{12}{|c|}{ Fungicide rate and Fungal pathogen } \\
\hline & \multicolumn{4}{|c|}{$0.3 \mu \mathrm{M}$} & \multicolumn{4}{|c|}{$3.0 \mu \mathrm{M}$} & \multicolumn{4}{|c|}{$30 \mu \mathrm{M}$} \\
\hline & $\mathrm{Ca}^{\mathrm{y}}$ & $\mathrm{Cf}$ & $\mathrm{Cg}$ & Fo & $\mathrm{Ca}$ & $\mathrm{Cf}$ & $\mathrm{Cg}$ & Fo & $\mathrm{Ca}$ & $\mathrm{Cf}$ & $\mathrm{Cg}$ & Fo \\
\hline$\overline{C A Y-1}$ & 27 & 15 & 18 & 1 & -99 & -85 & -100 & -3 & -99 & -100 & -100 & -29 \\
\hline Benomyl & 20 & -29 & -20 & -3 & 30 & -95 & -83 & -6 & 25 & -96 & -71 & -83 \\
\hline Captan & 12 & 18 & 16 & 0 & -99 & -98 & -98 & -23 & -100 & -99 & -100 & -100 \\
\hline Iprodione & 11 & 5 & 6 & -8 & 7 & 11 & 6 & -9 & 41 & 52 & 22 & 5 \\
\hline
\end{tabular}

$\mathrm{z}$ Compared to the growth of each fungal species in unamended potato dextrose broth.

y $\mathrm{Ca}=$ Colletotrichum acutatum; $\mathrm{Cf}=$ Colletotrichum fragariae; $\mathrm{Cg}=$ Colletotrichum gloeosporioides; Fo $=$ Fusarium oxysporum . 